\title{
Agility performance in athletes of different sport specializations
}

\author{
Erika Zemková* and Dušan Hamar \\ Faculty of Physical Education and Sports, Comenius University, Bratislava, Slovak Republic
}

Copyright: @ 2014 E. Zemková and D. Hamar. This is an open access article licensed under the Creative Commons Attribution License (http://creativecommons.org/licenses/by/4.0/).

\begin{abstract}
Background: Data on agility skills in different populations using pre-planned, change of direction speed tests have previously been reported. However, there are no available data on the agility times of athletes specializing in different sports obtained from Reactive agility tests. Objective: The study compares agility time in groups of athletes of different sports where agility is one of the limiting factors of performance. Methods: Altogether 282 athletes of 14 sport specializations performed the Agility test. Their task was to touch, as fast as possible, with either the left or the right foot, one of four mats located outside each of the four corners of a $0.8 \mathrm{~m}$ square. The mats had to be touched in accordance with the location of a stimulus in one of the corners of a screen. The test consisted of 60 visual stimuli with random generation of their location on the screen and a time of generation of 500 to 2,500 ms. The result was a sum of the 32 best agility times. Results: The Agility test has been found to be sensitive in distinguishing groups of athletes of different sport specializations. Table tennis players, badminton players, fencers, tae-kwon-do competitors and karate competitors showed the best agility times $(<350 \mathrm{~ms})$, followed by ice-hockey, tennis, soccer, volleyball, basketball, and hockeyball players $(350-400 \mathrm{~ms})$, then aikidoists $(400-450 \mathrm{~ms})$, and finally judoists and wrestlers (450-500 ms). Conclusions: The best agility times are in athletes of racquet sports, followed by competitors of combat sports with reactions to visual stimuli, then players of ball sports, and finally competitors of combat sports with reactions to tactile stimuli. Since this is the first study testing agility skills using the Reactive agility test in athletes of different sport specializations, data obtained can be used for comparison of athletes within particular sports.
\end{abstract}

Keywords: agility test, agility time, combat sports, sports games

\section{Introduction}

For many years, agility has been considered to be the ability to execute fast movements and to stop and restart rapidly. As a result, the majority of agility research has been devoted to pre-planned, change of direction speed tests. These tests (Illinois Agility Run, Shuttle Run test, Zig Zag Test, 505 Agility test, Hexagon test, Quadrant Jump Test, T-Test, 10 meter shuttle, Quick Feet Test, Side-step Test, 20 Yard Shuttle, Agility Cone Drill, 3-Cone Drill, Box Drill, AFL Agility Test, Arrowhead Drill, 20 Yard Agility, Balsom Agility Run, Lane Agility Drill, Shuttle Cross Pick-Up, etc.) have been proposed to measure speed and agility. Although there is great variation among the tests used, most of them do not involve reactions to stimuli, and therefore do not evaluate the cognitive component of agility

\footnotetext{
* Address for correspondence: Erika Zemková, Department of Sports Kinanthropology, Faculty of Physical Education and Sports, Comenius University in Bratislava, Nábr. arm. gen. L. Svobodu 9, 81469 Bratislava, Slovak Republic. E-mail: zemkova@fsport.uniba.sk
}

performance. However, many sports (soccer, basketball, tennis, ice hockey, badminton, racquetball/squash, volleyball, baseball/softball, lacrosse, american football, wrestling, boxing, fencing) which are ranked highest for agility require changes of direction in response to a stimulus (e.g., movement of the ball or a player). Another general feature of field and court sports is that actions are performed alongside the offensive player's movements; thus they involve some sort of competition. Therefore, testing and training conditions should mimic these sport-specific demands.

Recently, agility has been defined as a rapid wholebody movement with a change of velocity or direction in response to a stimulus (Sheppard \& Young, 2006). The use of tests of agility that combine changes of direction and/or speed with cognitive measures is encouraged in practice. Such new Reactive agility tests also include anticipation and decision-making components in response to the movements of a tester. Sheppard, Young, Doyle, Sheppard, and Newton (2006) have found that the Reactive agility test distinguishes between players of different performance levels in Australian football, while traditional closed skill sprint 
and sprint with direction change tests do not. Similarly, Farrow, Young, and Bruce (2005) showed that the highly-skilled group was significantly faster in both the reactive and planned test conditions relative to the lesser-skilled group, while the moderately-skilled group was significantly faster than the lesser-skilled group in the reactive test condition only.

Indeed, agility skills that involve three informationprocessing stages (i.e., stimulus perception, response selection, and movement execution) represent a crucial part of performance in many sports. Therefore, their assessment should be considered an integral part of functional testing in young beginners and professional athletes alike.

In practice, Reactive agility tests that can be carried out in the playing field or gym are preferred. A computer-based portable system consisting of four contact switch mats connected by means of an interface to the computer can be used for this purpose. The system generates stimuli and measures total agility time (AT) and $\mathrm{AT}$ in each direction of movement. There are a number of test settings varying in the time of generation (constant or random), the number of stimuli, their forms and colors, as well as the color of the background.

The task of the subject is to touch, as fast as possible, with either the left or right lower limb, one of the four mats located outside the four corners of a $0.8 \mathrm{~m}$ square. Mats have to be touched in accordance with the location of the stimulus in one of the corners of the screen. Besides reacting from a position in the middle of the square, subjects may respond from the location of the last stimulus.
This test has been found to be sensitive in distinguishing subjects of different ages (Zemková, 2007; Zemková \& Hamar, 2014). However, its ability to discriminate subjects of different performance levels has not yet been determined. It may be assumed that agility time differs significantly between athletes with different demands on agility skills, and is specific to those responding to visual stimuli. Verification of this hypothesis was accomplished by comparison of agility times in groups of athletes of different sport specializations.

\section{Methods}

\section{Participants}

Altogether 282 (male and female) athletes of different sport specializations volunteered to participate in the study (Table 1). They were required to be active in a particular sport. Only participants who met the inclusion criteria were included in the study. They were asked to avoid any strenuous exercises during the study. All of them were informed of the procedures and the main purpose of the study. The procedures presented were in accordance with the ethical standards on human experimentation as stated in the Helsinki Declaration.

\section{Procedure}

Prior to the study, participants attended a familiarization session during which the testing conditions were explained and trial sets carried out. Afterwards they performed the Agility test (Figure 1). Their task was to touch, as fast as possible, with either the left or the

Table 1

Characteristics of groups of athletes (mean $\pm S D$ )

\begin{tabular}{lcccc}
\hline Group & $n$ & Age (years) & Height $(\mathrm{cm})$ & Weight $(\mathrm{kg})$ \\
\hline Wrestlers & 13 & $26.2 \pm 3.1$ & $175.0 \pm 4.8$ & $85.7 \pm 7.8$ \\
Judo competitors & 14 & $24.1 \pm 3.8$ & $173.9 \pm 5.6$ & $80.2 \pm 8.8$ \\
Hockeyball players & 22 & $22.7 \pm 2.8$ & $177.1 \pm 5.4$ & $76.7 \pm 6.5$ \\
Aikido competitors & 18 & $25.3 \pm 4.1$ & $173.8 \pm 4.5$ & $73.9 \pm 5.5$ \\
Basketball players & 32 & $20.4 \pm 1.8$ & $187.5 \pm 6.1$ & $78.9 \pm 7.7$ \\
Volleyball players & 21 & $21.3 \pm 2.6$ & $186.9 \pm 6.2$ & $74.0 \pm 5.4$ \\
Soccer players & 26 & $22.7 \pm 2.9$ & $179.7 \pm 4.7$ & $70.8 \pm 4.9$ \\
Tennis players & 17 & $20.7 \pm 3.2$ & $175.4 \pm 5.1$ & $71.1 \pm 5.1$ \\
Ice-hockey players & 16 & $22.9 \pm 3.7$ & $177.0 \pm 5.4$ & $77.8 \pm 6.4$ \\
Karate competitors & 27 & $23.9 \pm 3.7$ & $175.9 \pm 5.7$ & $68.4 \pm 7.2$ \\
Tae-kwon-do competitors & 23 & $21.9 \pm 2.6$ & $172.8 \pm 3.8$ & $68.7 \pm 6.5$ \\
Fencers & 11 & $20.8 \pm 2.4$ & $175.4 \pm 4.1$ & $65.1 \pm 6.6$ \\
Badminton players & 15 & $21.8 \pm 2.0$ & $176.5 \pm 3.8$ & $64.7 \pm 5.7$ \\
Table tennis players & 27 & $24.6 \pm 4.5$ & $172.8 \pm 2.9$ & $64.1 \pm 5.4$ \\
\hline
\end{tabular}


a

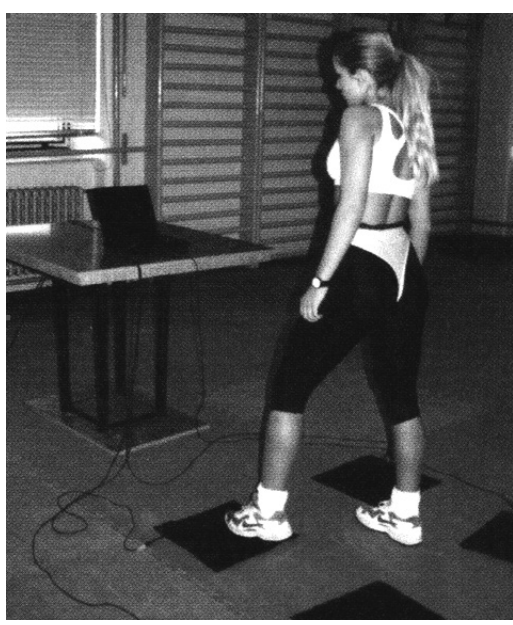

b

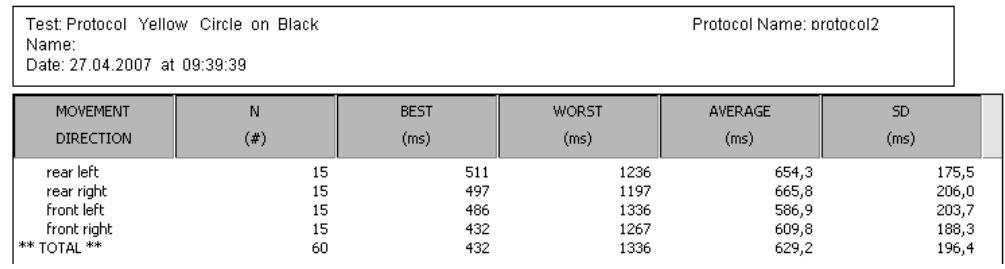

Figure 1. The Agility test (a), summary report of the test (b)

right foot, one of four mats located outside the four corners of a $0.8 \mathrm{~m}$ square. The mats had to be touched in accordance with the location of a stimulus in one of the corners of a screen. The test consisted of 60 visual stimuli with random generation of their location on the screen and the time of generation of 500 to $2,500 \mathrm{~ms}$. The result was a sum of the 32 best agility times.

\section{Agility testing}

Agility time was measured by means of the computer based FiTRO Agility check system (FiTRONiC s.r.o., Bratislava, Slovak Republic). The reliability of the test procedure had been verified previously, and the testing protocol had been standardized by the examination of 196 participants (Zemková \& Hamar, 1998a). The analysis of repeated measurements showed a measurement error of $7.1 \%$, which is within a range comparable to common motor tests. The mean of the best 8 agility times in each direction has been found to be the most reliable parameter of the test consisting of 3 sets of 60 stimuli (15 in each direction) with random generation of their location. However, when the same protocol (i.e., the same location of stimuli in each trial) was used repeatedly, agility time significantly decreased after each trial. Participants were most likely able to remember the position of the initial stimuli, which contributed to better results in successive trials. Therefore, the result of the Agility test is a sum of the 32 best multi-choice agility times in four directions as a response to stimuli generated by the computer in one of the corners of the screen.

\section{Statistical analysis}

Data analysis was performed using the SPSS statistical program for Windows (Version 18; SPSS, Inc., Chicago,
IL, USA). The calculation of the sample size was carried out with $\alpha=0.05$ ( $5 \%$ chance of type I error) and $1-\beta=.80$ (power $80 \%$ ) and using the results from our preliminary studies that showed differences in agility time between athletes of different sports (Zemková \& Hamar, 1998b; Zemková \& Hamar, 1998c; Zemková \& Hamar, 1999). This provides a sample size of 16 subjects for this study. However, the sample size in four groups was below this limit (from 11 to 15) as the inclusion criteria required participants to be active in a particular sport. Therefore, the statistical power for a group of size $n$ ranged from .76 to .85 .

A series of one-factor ANOVA with a Bonferroni post hoc test was used to determine differences in agility time between groups of athletes of different sport specializations. The criterion level for significance was set at $p \leq .05$. Sex data, determined to be normally distributed, were analyzed in previous studies using the independent samples $t$-test and showed no significant differences in agility time between men and women (Zemková \& Hamar, 1998b; Zemková \& Hamar, 1998c; Zemková \& Hamar, 1999). Data on agility time for all examined groups are presented as the mean \pm the standard deviation.

\section{Results}

The Agility test has been found to be sensitive in distinguishing groups of athletes of different sport specializations and has shown that some differences do exist among the mean values for the examined groups at $\mathrm{p} \leq .05$. The mean values of agility time and the standard deviations for each group of athletes 


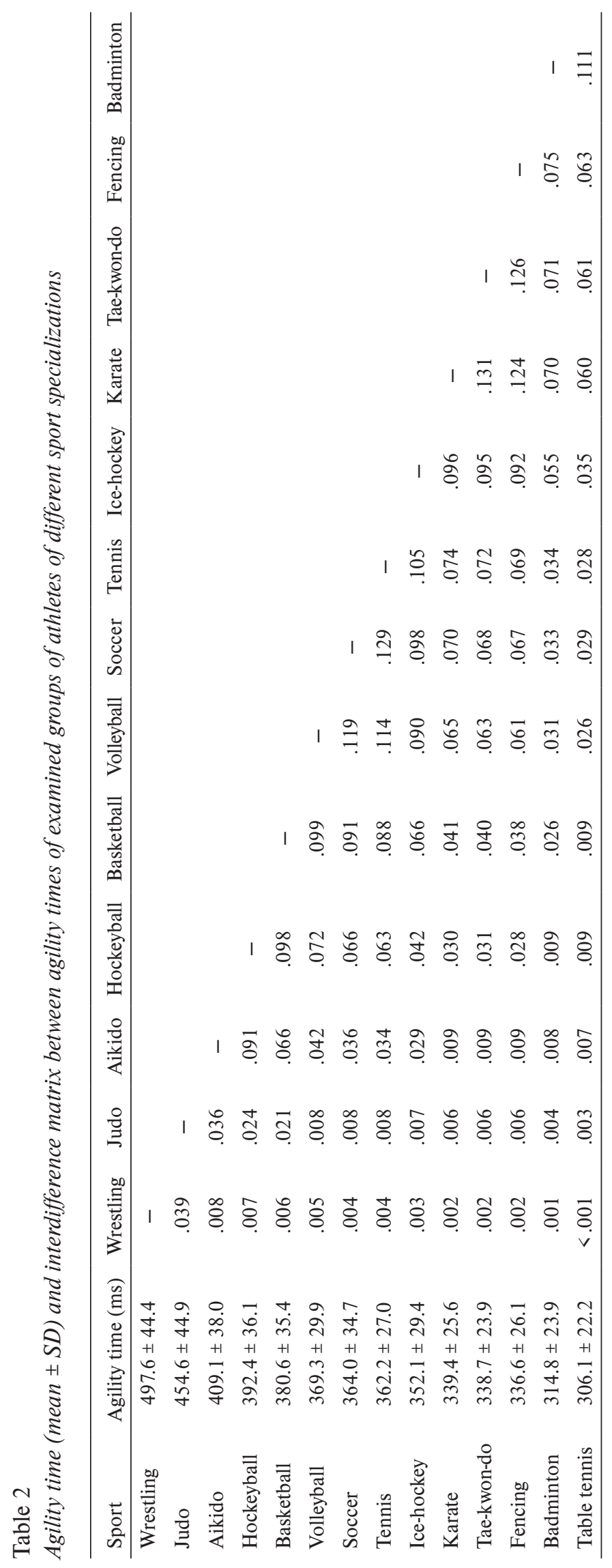


are presented in Table 2. In addition, the variability among subjects showed high $F$ values for agility time $\left(\mathrm{F}_{1,280}=34.48, \mathrm{p}<.001\right)$ indicating that the subjects differed significantly in their performance.

As shown in Figure 2, the best agility times have been found in table tennis players, badminton players, fencers, tae-kwon-do competitors and karate competitors $(<350 \mathrm{~ms})$, followed by ice-hockey, tennis, soccer, volleyball, basketball, and hockeyball players (350-400 ms), then aikidoists (400-450 ms), and finally judoists and wrestlers (450-500 ms).

Accordingly, these sports were divided into four basic categories (Figure 3) that can be used for the comparison of individual athlete data and changes in the data during training.

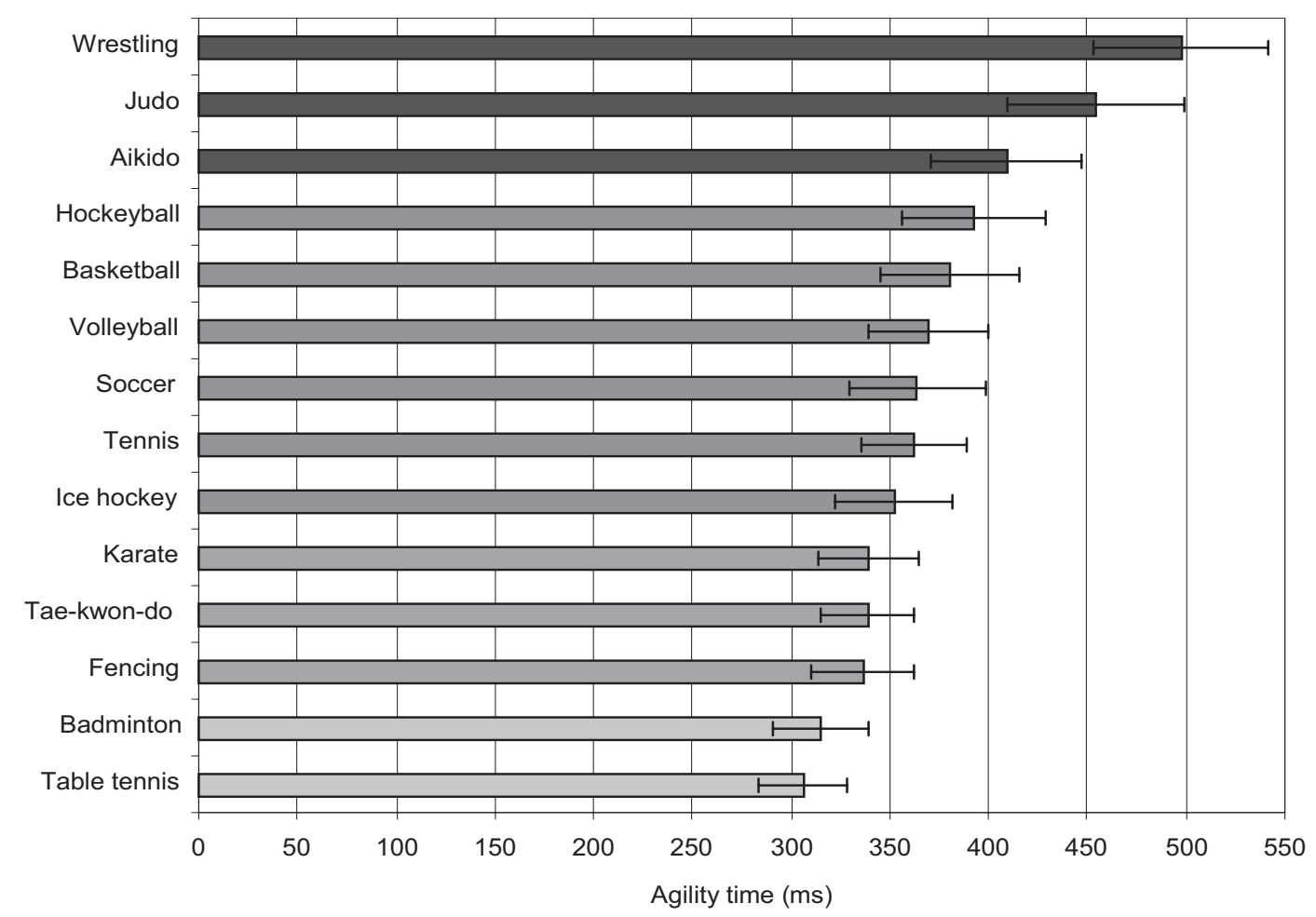

Figure 2. Agility time in groups of athletes of different sport specializations

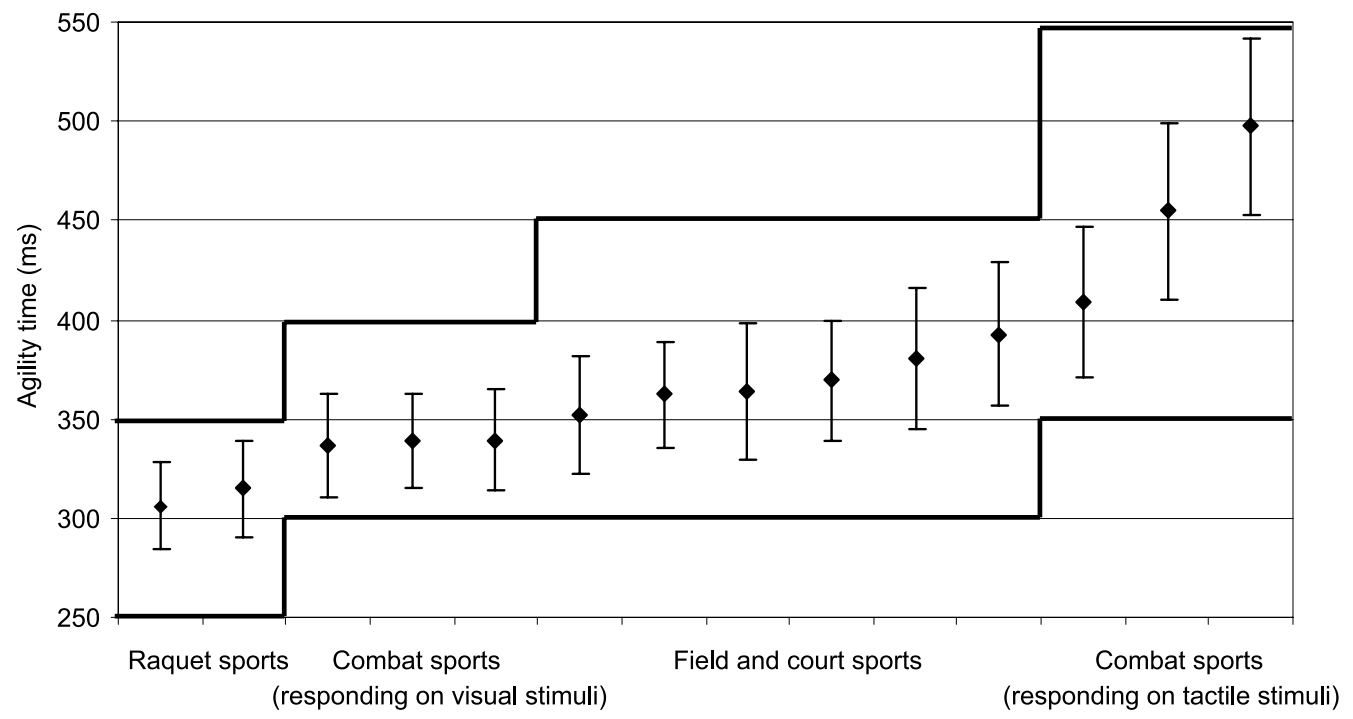

Figure 3. Agility time $( \pm \mathrm{SD})$ in different sports divided in four basic categories 


\section{Discussion}

The study showed that the Agility test discriminates between groups of athletes with different demands on their agility skills. The results are in agreement with preliminary findings which showed better agility times in athletes responding to visual rather than tactile stimuli (Zemková \& Hamar, 1998b, 1998c, 1999). Moreover, differences in agility time have reflected the actual ranking of athletes, for instance, at different playing positions (center, forward, guard) in basketball players (Zemková \& Hamar, 2013), between hockeyball players and hockeyball goalkeepers (Divald, 2012), in different corners of the hockey goal in ice-hockey goalkeepers (Tóth et al., 2010), and in different movement directions in badminton players (Štefániková \& Zemková, 2011). The data obtained in these studies form the basis for the design of training programs specifically focused on the improvement of agility skills in a particular movement direction.

Similar to strength and speed abilities, assessment of agility also requires a sport-specific approach. In order to obtain parameters of agility skills relevant to a particular sport, the test closest to the one used during training or competition should be preferred. In recent years, several sport-specific versions of the Agility test have been developed. These tests vary in: a) number of contact mats $(2$ or 4$), b)$ the distance between mats and subject $(0.4 \mathrm{~m}, 0.8 \mathrm{~m}, 1.6 \mathrm{~m}$ or $3.2 \mathrm{~m})$, c) their alignment (square or semi-circular), d) positioning (underfoot or at the height of the thorax), and e) size $(6.5 \times 6.5 \mathrm{~cm}$ or $35 \times 35 \mathrm{~cm})$ (Zemková \& Hamar, 2009). The number of stimuli, their time of generation and their colour have also been modified according to the requirements of particular sports. The most used versions of the Agility test are as follows: a) using two mats for forehand and backhand movements in tennis players, b) moving shorter distances for karate competitors and longer distances for basketball players, c) responding to the same stimulus located in four corners for ice-hockey players and to stimuli of different forms or colors located in a semi-circle for ice-hockey goalies, d) touching the mats with the lower limbs for soccer players and with upper limbs for basketball players, and e) using a smaller target for karate competitors and bigger target for basketball players (Zemková \& Hamar, 2013). Another example is the test for goalkeepers consisting of two stimuli for the upper limbs and two stimuli for the lower limbs. Experience has shown that the assessment of agility performance under sport-specific conditions represents a more appropriate alternative than the original version of the Agility test.

Measurements of simple and multi-choice reaction times and of movement time may provide additional information on the components of agility performance. In the Reaction test, the participant may respond to either one (simple reaction time) or more stimuli of different forms or colors (multi-choice reaction time).

Decision time has a strong influence on total agility time and therefore perceptual skill should be addressed in agility testing and training. Young and Willey (2009) found that of the three components that make up the total time, decision time had the highest correlation $(r=.77, p<.001)$ with the total time. This correlation with total time was greater than for response movement time $(r=.59)$ or tester time $(r=.37)$, indicating that decision time was the most influential of the test components for explaining the variability in total time. The decision time component within the reactive test condition also revealed that the highly-skilled players made significantly faster decisions than the lesserskilled players (Farrow, Young, \& Bruce, 2005). The results of Gabbett and Benton (2009) also demonstrate that the decision and movement times on the Reactive agility test were faster in higher-skilled players, without compromising response accuracy. It is therefore of practical significance to assess the perceptual components of agility performance.

A new approach in the functional assessment of athletes is the testing of agility skills under simulated competitive conditions. It has been found that agility time is better when the Agility test is performed in simulated competitive (Agility dual), rather than non-competitive (Agility single) conditions (Zemková, Vilman, Kováčiková, \& Hamar, 2013). An Agility test in the form of simulated competition should be preferred for children and young athletes in order to enhance their arousal level and motivation. Such an exercise may also represent an appropriate means for agility training, particularly in young athletes (Zemková, 2012).

Recently, Kováčiková (2012) evaluated the changes in reaction and speed abilities after 8 weeks of agility training under simulated competitive and non-competitive conditions. A group of 22 fit young men, divided into two experimental groups, underwent the same agility training (two times a week for 30 minutes). However, while experimental group 1 performed the training in the form of simulated competition (i.e., either in pairs or in a group), experimental group 2 performed the same training under non-competitive conditions. Prior to and after the training, agility times in the tests of Agility single and Agility dual were measured. Additionally, simple reaction time, multi-choice reaction time, maximal velocity of step initiation, frequency of movement of the lower limbs, power in the concentric phase of take off in a 10 second test of repeated jumps, jump height, and contact time after drop jump were measured. After 8 weeks of agility training, a more 
pronounced improvement of agility time was found in the test of Agility dual in the group trained in the form of simulated competition than in the group that carried out the same training, but without competitive components ( $18 \%$ and $-0.6 \%$, respectively). However, there were no significant differences in the changes of other parameters of reaction and speed abilities after training under simulated competitive and non-competitive conditions. These findings indicate that agility training performed in the form of simulated competition represents a more effective means for the improvement of agility skills than the same training under non-competitive conditions. However, such a training does not contribute to more pronounced improvement of other reaction or speed abilities.

Since agility skills represent a crucial part of performance in many sports, their assessment should be considered an integral part of the functional testing of athletes. Data on agility skills in different populations using pre-planned, change-of-direction speed tests have been reported. However, there were no available data on agility times in different sports obtained from Reactive agility tests. This is the first study that provides data on the agility time in the Reactive agility test of athletes of different sport specializations.

\section{Conclusions}

The Agility test discriminates between groups of athletes with different demands on their agility skills. The best agility times have been found in athletes of racquet sports, followed by competitors of combat sports with reactions to visual stimuli, then players of ball sports, and finally competitors of combat sports with reactions to tactile stimuli. These data on agility times in different sports can be used for the decision making process in related sports, enabling comparisons to be made with individual athlete data and changes in the data during training. Taking into account significantly better agility time in athletes responding to visual rather than tactile stimuli, the Agility test may be recommended primarily for athletes used to responding to various forms of visual stimuli (e.g., the ball).

\section{Acknowledgment}

This study was supported through a Scientific Grant Agency of the Ministry of Education of Slovak Republic and the Slovak Academy of Sciences (No. 1/0373/14).

\section{References}

Divald, P. (2012). Rýchlost reakcie hráčov a brankárov v hokejbale [Speed of reactions of players and goalies in hockeyball]. Bratislava: Comenius University, Faculty of Physical Education and Sports.

Farrow, D., Young, W., \& Bruce, L. (2005). The development of a test of reactive agility for netball: A new methodology. Journal of Science and Medicine in Sport, 8, 52-60.

Gabbett, T., \& Benton, D. (2009). Reactive agility of rugby league players. Journal of Science and Medicine in Sport, 12, 212-214.

Kováčiková, Z. (2012). Zmeny reakčno-rýchlostných schopností po rôznych formách agility tréningu [Changes of reaction-speed abilities after different forms of agility training] (Doctoral dissertation). Comenius University, Faculty of Physical Education and Sports, Bratislava.

Sheppard, J. M., \& Young, W. B. (2006). Agility literature review: Classifications, training and testing. Journal of Sports Sciences, 24, 919-932.

Sheppard, J. M., Young, W. B., Doyle, T. L., Sheppard, T. A., \& Newton, R. U. (2006). An evaluation of a new test of reactive agility and its relationship to sprint speed and change of direction speed. Journal of Science and Medicine in Sport, 9, 342-349.

Štefániková, G., \& Zemková, E. (2011). Posudzovanie disjunktívnych reakčno-rýchlostných schopností do jednotlivých smerov pohybu $\mathrm{v}$ bedmintone [Assessment of disjunctive reaction-speed abilities in each movement direction in badminton]. In J. Suchý a kol. (Eds.), Proceedings of the Scientific Conference "Sciencia movens" (pp. 117-121). Prague: Charles University.

Tóth, I., Bielik, V., Bínovský, A., Duchoslav, L., Duvač, I., Filc, J., ... Žák, F. (2010). Ladový hokej: vysokoškolská učebnica aplikovaných predmetov pre trénerov špecializácie $v$ ladovom hokeji [Ice-hockey]. Bratislava: TO-MI Ice Hockey Agency.

Young, W. B., \& Willey, B. (2009). Analysis of a reactive agility field test. Journal of Science and Medicine in Sport, 13, 376-378.

Zemková, E. (2007). Agility in children. Tělesná výchova a sport mládeže, 73(2), 38-39.

Zemková, E. (2012). Assessment of agility skills in sport and physical education. In Proceedings of the International Forum of Physical Education and Sports Science (p. 15). Chandigarh: Panjab University.

Zemková, E., \& Hamar, D. (1998a). Test disjunktívnych reakčno-rýchlostných schopností dolných končatín [Test of disjunctive reaction-speed abilities of lower limbs]. In M. Janura (Ed.), Sborník referátu z celostátní studentské vědecké konference v oboru kinantropologie (pp. 178-181). Olomouc: Palacký University.

Zemková, E., \& Hamar, D. (1998b). Disjunktívne reakčnorýchlostné schopnosti u športovcov rôznych špecializácií [Disjunctive reaction-speed abilities in athletes of different specializations]. In Proceedings of the Scientific Conference "37. východoslovenské lekárske dni pri príležitosti 50. výročia založenia Lekárskej fakulty a Fakultnej nemocnice v Košiciach" (p. 13). Nový Smokovec: Slovak Society of Sports Medicine. 
Zemková, E., \& Hamar, D. (1998c). Disjunktívne reakčnorýchlostné schopnosti v úpolových športoch [Disjunctive reaction-speed abilities in combat sports]. In Proceedings of the scientific conference "Súčasný stav a perspektívy Sokola" (pp. 112-117). Košice: Technical University.

Zemková, E., \& Hamar, D. (1999). Disjunktívne reakčnorýchlostné schopnosti u športovcov rôznych špecializácií [Disjunctive reaction-speed abilities in athletes of different specializations]. Slovenský lekár, 9, 145-146.

Zemková, E., \& Hamar, D. (2009). Toward an understanding of agility performance. Boskovice: Albert.
Zemková, E., \& Hamar, D. (2013). Assessment of agility performance under sport-specific conditions. Asian Journal of Exercise and Sports Science, 10, 47-60.

Zemková, E., \& Hamar, D. (2014). Age-related changes in agility time in children and adolescents. International Journal of Science and Research, 3(11), 280-285.

Zemková, E., Vilman, T., Kováčiková, Z., \& Hamar, D. (2013). Reaction time in the Agility test under simulated competitive and non-competitive conditions. Journal of Strength and Conditioning Research, 27, 3445-3449. 